\title{
Development Result of Kecombrang Fruit Become Various Products for Home Industry
}

\author{
Jokebet Saludung \\ Universitas Negeri Makassar, Makassar, Indonesia
}

\begin{abstract}
Prospect of developing kecombrang fruit has produced various products for home industry (research result of Stranas, 2015-2016) and need to disseminated through this paper. Research for prospects of kecombrang fruit development has implemented since 2014 even continues until now. The goal is to produce products various for home industry. The survey results show that kecombrang plants everywhere but still in the form of wild plants because it is not known in general the utilisation by the community. Therefore, the results should be disseminated to be known by the community as one of the most useful local food. $R \& D$ in the form of experiments in the laboratory and field has produced a variety of products with formulas, flavours, colours, textures, aromas, endurance, labels and packaging that are better and viable for home industry. Prototype product model is the best used as training materials and community empowerment by using life skill learning model in cooperation with Village Community Empowerment Board. Evaluation data were collected by (1) organoleptic test by panellist, (2) observation, (3) interview, (4) questionnaire, (5) FGD, (6) nutritional product analysis. Data were analysed by descriptive and qualitative. Evaluation of research results indicates that there are products various that have produced. Feasible for home industry and need to be disseminated are: Drink Kecombrang Josani Aneka Rasa, Instant Beverages, Sugar, Candy, Various Ice Cream Kecombrang, with formula, taste, colour, texture, Aroma, endurance, labels and better packaging. The results of organoleptic tests show that the products that have produced are trendy. Nutritional content of kecombrang products is high. Result Evaluation of research indicates that kecombrang can make many products which very liked by society and can become the home industry to increase community productivity.
\end{abstract}

Keywords: Kecombrang, Fruit Development, Various Products, Home

\section{Introduction}

This research is research and development in the form of the experiment which continued with field research, using Model Joke which has been developed before to become guidance in conducting research. The study entitled: "Prospect of Kecombrang Fruit Development into Home Industry" is a National Strategic Research Scheme. Based on the Handbook of Implementation Research and Community Service In Higher Education X Edition [1][2]. Product process of science in the kind of method, blueprint, the model of prototype product, system, policy or design that is strategic and national scale, or appropriate technology that can be directly utilised by the community, and additional output in the form of textbooks.

Papers should describe the background of the subject, the authors work, including the methods used, results and concluding the discussion on the importance of the work. Papers prepared in English and SI units must utilise. Technical terms should explain unless they were considered to be known to the conference community.

This research base on the conclusions of various sources [3][7]. That kecombrang is a very useful and contains high nutrients needed by the body, from bamboo shoots, shoots, stems, leaves, bumps, flowers and fruit, and can be made various products. Kecombrang is very beneficial for human life, among others, as a vegetable ingredient, seasoning flavouring different kinds of archipelago cuisine, neutralise the fishy aroma of fish, contain antioxidants that can prevent cancer growth and premature ageing, as a natural deodorant [3]. So people who like to consume kecombrang freed from unpleasant body odour, as a resistant to microbial and natural preservative of food, as an ornamental plant. Rich in vitamins and minerals, containing saponin, flavonoids, polyvinyl, and essential oils. Efficacious as a traditional medicine to cure measles, earache, various liquid milk of mother, as deodorant, cleaner of blood and wound. The nutritional content is very high. The nutritional content for 100 grams of kecombrang is: 4.4 grams carbohydrate, (2) 1.0 gram fat, (3) 1.3 grams protein, (4) 91 grams water, (5) 1.2 gram fiber, (6) $32 \mathrm{mg}$ calcium, (7) $4 \mathrm{mg}$ iron, (8) $27 \mathrm{mg}$ magnesium, (9) 30 mg phosphorus, (10) $541 \mathrm{mg}$ potassium, (11) $0.1 \mathrm{mg}$ zinc. Many grow wild everywhere very quickly, but the utilisation is still very limited because the public does not widely know it. Agustina declared that is very useful for human life, ranging from leaves and flowers [8]. Kecombrang (Etlingera elatior) is a rooted plant of rhizome-shaped vegetation that looks like ginger and galangal. In Indonesia, kecombrang different names that are in Sumatera is called kola, there, cekala and puwar kinjung. In Java the name honje, rombeka, combrang, siantan and cumbrang. In Sulawesi, the name is atimengo, bubago, katimbang, and patikala. In Maluku, his name is salahawa and petikala. All parts of the kecombrang can utilise, but only traditionally used by a small number of people in some areas. Therefore, it is necessary to disseminate through research to become more known and can be widely utilised by the community. The writer has tried to examine the flowers and fruit kecombrang to be made into drinks as syrup kecombrang Josani flavour variety and then developed into instant beverages, candy, hard candy, and various of Josam ice cream. The problem is what products can produce from fruit kecombrang? How to develop a variety of quality products and favoured by the community and can be prepared into a more marketable as the home industry? How to motivate people to cultivate of kecombrang as raw material, to increase productivity. 


\section{International Journal of Science and Research (IJSR) \\ ISSN (Online): 2319-7064}

Index Copernicus Value (2015): 78.96 | Impact Factor (2015): 6.391

\section{Method}

The type of this research is research and development ( $R$ \& D) in the form of experiment in laboratory and field. Using Joke Model (R \& D Model) development result from The General Model is the model of development of Educational Technology from Plomp and Falletta [9][10]. The Plomp model can be used in education and training, consisting of five components: the preliminary investigation, design, realisation, test/ evaluate and revision, and implementation. Evaluation of training program using Kirkpatrick model with four components, namely: reaction, learning, behaviour, and result. The Kirkpatrick Model and Plomp Model developed into Joke Model as the needs of this study with the components are a) Preliminary findings; b) Development plan; c) Model/prototype; d) Test/validation and revision; e. Implementation; f) Evaluation (reaction, learning, behaviour, outcome); g) Product dissemination, because of its relevance to this research needs [4][5]. Why is the Kirkpatrick Model and Plomp Model developed into a Model Joke? Because this Stranas Research contains training in field research that should evaluate for its success rate. Joke Model which used as guidelines for the implementation of $\mathrm{R} \& \mathrm{D}$ to produce various of products from kecombrang [11]. Based on preliminary findings, an explanation of the problem, content analysis, conditions, objectives, implementation process, and results achieved from the first year of research. In the development plan, it explains what should be developed, upgraded or improved from existing products, forms of activities, research strategies used in field area either in the laboratory or required tools, materials, product model design, processing tools, test instruments, Evaluation tool needed. Preparing panellists for organoleptic tests of experimental results in the laboratory and field research results. Laboratory testing to produce the prototype of advanced product model ready to be trained in the field research, repeatedly done until the results obtained meet criteria by using organoleptic test by the panellist. The best results serve as training materials in the form of textbooks by advanced product development, preparation of processing equipment, packaging, test and validation test kits. At the implementation stage, the best laboratory test results are exercised to the community using a life skill training model-based on the home industry which it was developed previously [12]. During the training, evaluations were conducted to find out how the participants reacted, the motivations for what they had gained, how the learning process and outcomes, how the behaviour changes, what issues/products the community gained and what factors influenced [13], and how to follow-up the training results. Everything evaluated. Results and various products were analysed for nutritional content at the Central Laboratory of Makassar from July to August 2016. Subsequently, the dissemination conducted through seminars, article writing in proceedings, product marketing, participation in educational exhibitions at UNM (2016), at the village level of PKK competition, Sub-districts, districts and other activities at the celebration of Independence Day on August 17, 2015-2016. Various products kecombrang have been included in the race of Jambore PKK at Toraja North and won as the first champion. A research laboratory in the laboratory of PKK of Technical Faculty of Universitas Negeri Makassar. Field training in North Toraja District. The study population is the local product crops which the ingredients and seedlings are still taken from Palopo, while the research target is the people of South Sulawesi. Samples were taken purposively for both laboratory research and trials, and field research in North Toraja District. The study procedure conducted for two years. The first year (2015) has a tryout in laboratory and field research, to make kecombrang syrup and drinks Josani flavoured variety, with the right formula (prototype model). The second year of research with laboratory research conducted three times. Followed by training on making Instant Drinks, Candy, Hard candy, many kinds of Ice Creams, all brands of Josam, cultivation plant of kecombrang, evaluation and dissemination. The process of research according to the existing stage in Joke Model. The technique of data collecting is laboratory data and training data using organoleptic test by panellist with hedonic scale [14]. Others of field data were collected using observation, interview, checklist, FGD, and questionnaire. According to Sekaran, Panels, like a focus group, another source of primary information for research purposes. The expert members of the composition board and the research that uses them have collected a group study [15]. Data analysed by descriptive and qualitative analysis technique. It expected that the community could access technology and resource utilisation to increase the productivity and family income [16] through the development of various products of kecombrang into the home industry.

The measurable performance indicators are resulting from this study [4][5] complete with instrument tool that is sheet score for the organoleptic test by the panellist, observation guidance, interview, checklist, FGD, questionnaire, document result of training and exhibition result [17][18][19]. Prototype models of kecombrang drinks with packaging as bottled and glasses, and prototype models of instant drinks, candy, hard candy, various of ice cream, with labels and packaging. Cultivation of kecombrang plants, research documents, reports and research articles. Different products result of the development of fruit kecombrang become the focus in this writing.

\section{Result and Discussion}

Research and development that started from the experiment in laboratory and field to develop of kecombrang fruit become a various product which deserves to made home industry have implemented. This research has produced various products from kecombrang. In the first year has built Model Joke, Training Model and Community Empowerment, Textbook of Training Based Home Industry [11][17][20]. All of them used as guidelines for the implementation of research in the laboratory and in the field to get prototype model of syrup and drink of kecombrang Josani with flavoured beverage products with the right formula and better quality of flavour, colour, texture, aroma, endurance, label and packaging. The best of laboratory results have become the teaching materials in training and empowerment with life skill learning model. In the second year, the research continued with the development of various products in the laboratory to get prototype product type of instant drinks, 


\section{International Journal of Science and Research (IJSR) \\ ISSN (Online): 2319-7064}

Index Copernicus Value (2015): 78.96 | Impact Factor (2015): 6.391

candy, hard candy, any ice cream, aroma, endurance, Labels and better packaging for field research materials in training and community empowerment. Organoleptic tests have collected data on laboratory results and field test results by panellists [21], observation, interviews, FGD, and questionnaires. Search results on the ground and the internet [7], found various types of plants that can process of kecombrang for the development of different products. From the results of the survey, analysis summary concluded that all parts could use, ranging from tubers, bamboo shoots, stems, leaves, tuna, flowers, fruit. These parts can use as vegetables, medicines, spices, chilli, soap, deodorant, antioxidants. Even the dried leaves can make wicker, leaf for wrapping cake and songklok. Flowers can make a sauce, fruit and tubers can use as spices and medicines. Also, it can be utilised to create various products for entrepreneurship [22]. However, developed in this study is fruit and flowers of kecombrang. Other sections while still will be further investigated. Some of the findings presented in this paper: plants, tubers, bamboo shoots, stems, shoots, leaves, flowers, fruit, as follows:
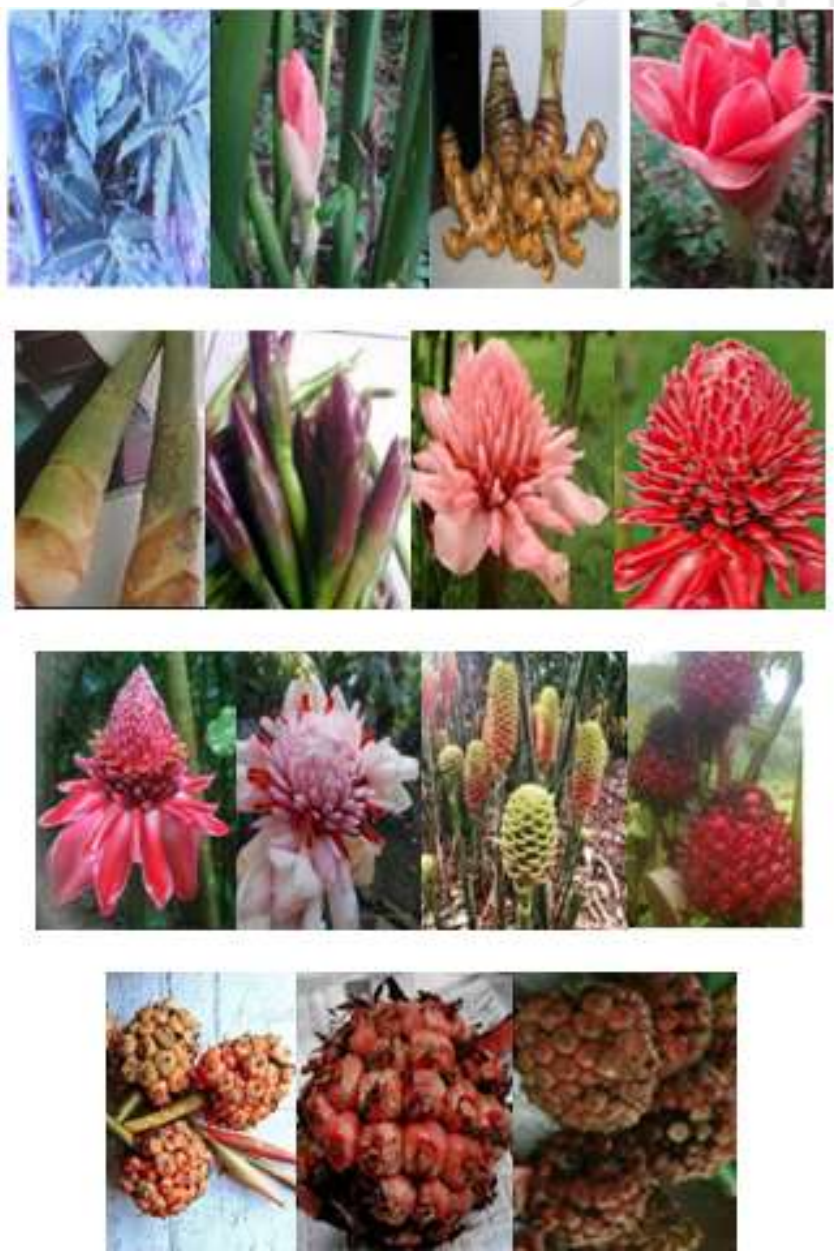

Figure 1: Crops, tubers, bamboo shoots, stems, leaves, and shoots, Various of flowers and kecombrang fruit

The results of the development of kecombrang fruit through research [4] [23] has led from Various products as follows:

1. Syrup and kecombrang drinks Josani flavoured different (Josani brand)

a. Josani Syrup and drink of Flavors Original Kecombrang Fruit. Made from kecombrang $1 \mathrm{~kg}$, sugar $2 \mathrm{~kg}, 1$ litre of water, egg white one egg. This syrup is used to make syrup and various flavoured drinks. Or go from $1 \mathrm{~kg}$ of fruit, kecombrang flowers 40 grams, sugar $1.50 \mathrm{~kg}$, water: 1.5 litres, egg white one egg. If you want to improve the colour of syrup can add three drops of red dye.

b. Josani Kecombrang Syrup with Strawbery Flavors Made from the syrup of kecombrang $800 \mathrm{cc}$, sugar 1 $\mathrm{kg}$, Strawberry 250 gr (already blended). Boiled for 25 minutes on medium heat.

c. Josani Syrup Kecombrang with of Dutch Eggplant Flavors. Made from a syrup of kecombrang $800 \mathrm{cc}$, sugar $1 \mathrm{~kg}$, Dutch eggplant 500 gr (blender). Boiled for 25 minutes on medium heat.

d. Josani Syrup Kecombrang with Sinamon Flavors. Made from the syrup of $800 \mathrm{cc}$, sugar $0 \mathrm{~kg}$, cinnamon 20 gram. Boiled for 30 minutes on medium heat.

e. Josani Syrup Kecombrang with Ginger Flavor. Made from the syrup of kecombrang $800 \mathrm{cc}$, sugar $0 \mathrm{~kg}$, ginger $100 \mathrm{gr}$ (already shredded). Boiled for 30 minutes on medium heat.

f. Josani Syrup Kecombrang with Wood Secang Flavors Sugars 1000 cc syrup, $0 \mathrm{~kg}$ sugar, wood water secang from 1 small slice $2 \times 2 \times 10 \mathrm{~cm}(20 \mathrm{~g})$ Boiled with 2 cups water to boil and filtered. Cooked for 25 minutes on medium heat. The colour will be orange yellow.

g. To get a drink directly drunk then the syrup is melted with 1:1 cooking water or according to taste. Label and its products as follows:
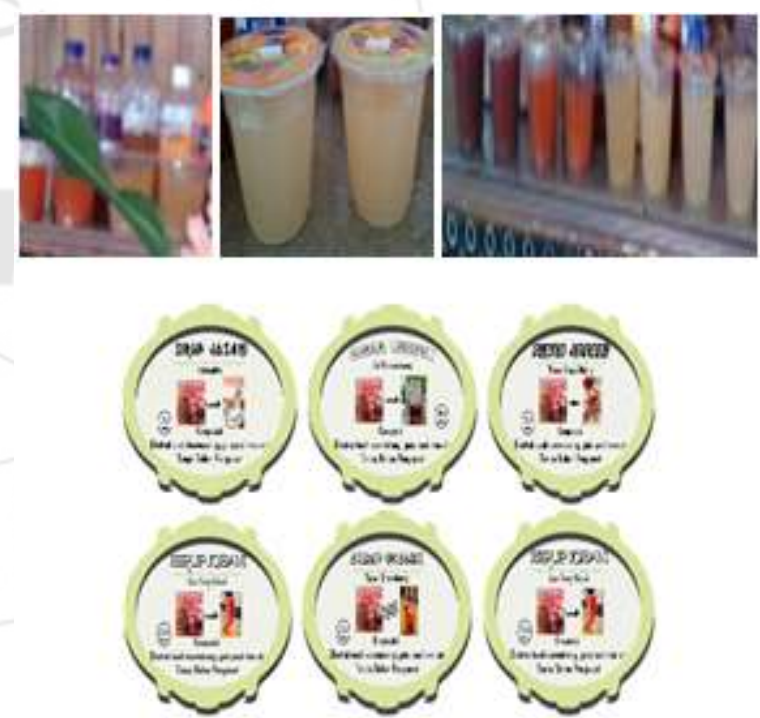

Figure 2: Label and Package Syrup and Drink Josani Various Flavors (Label can be put on the cover or in the bottle or boxed)

From the results of hedonic test analysis and hedonic quality based on organoleptic test results in taste, colour, texture and aroma, by panellists and consumers, the results of these standard prescription products are most preferred and favoured by stakeholders and users among the experimental tests. Results that have done In the laboratory and field test. Compared with many of these beverage products in general, the most preferred are syrup, and Josani flavored strawberry flavor $(100 \%)$, ginger flavor $(95 \%)$, brownish grass flavor $(92 \%)$, original flavor $(90 \%)$, cinnamon $(75 \%)$, and secang wood $(80 \%)$ [4].

\section{Volume 6 Issue 9, September 2017 www.ijsr.net}




\section{International Journal of Science and Research (IJSR) \\ ISSN (Online): 2319-7064}

Index Copernicus Value (2015): 78.96 | Impact Factor (2015): 6.391

2. Various advanced products of the Josam brand (Research Result) had produced [5]:

a. Instant drinks Kecombrang Josam. Juice of kecombrang made from $1 \mathrm{~kg}+1$ litre squeezed, filtered and precipitated, the water is removed and then dried and packed in sachets.Also can be done from dried beans until dried completely blended and sifted or left to half rough like tea, then packaged in sachets with tissue paper or plastic. Ready to be used and marketed.

b. The Kecombrang Candy of Josam. Made from 250 grams of sugar, 200 gr glucose, $1 / 2$ tsp cream of tartar, $200 \mathrm{ml}$ of the juice of kecombrang. Sugar and kecombrang juice mixed, stirring, bring to the boil, enter the glucose and cream of tartar, cook over low heat until the temperature is $140 \mathrm{C}$. Lift, pour the mould, cold and pack.

c. Hard Candy kecombrang Josam. Made from 1 packet of jelly, $300 \mathrm{ml}$ of cream sour, $250 \mathrm{gr}$ of sugar, $50 \mathrm{gr}$ of glucose, colour according to taste. Mix all ingredients, cook for 10 minutes over low heat while stirring, bring to a boil, remove and pour into a baking rectangle, Then cut into pieces, drying 2-3 days, then serve.

d. Ice Cream Shrunk Kecombrang, glasses and scones Josam. Made from Ice Cream with chocolate juice with 250 cc kecombrang juice, 20 gr of cinnamon juice, one can of sweetened condensed milk (milk powder $1 / 4 \mathrm{~kg}$ ), $50 \mathrm{gr}$ of cocoa powder, one bottle of coca cola. All ingredients are mixed and put into an ice cream machine. Done in the cup, cup, scone, and store in the freezer. Can also be shrunk.

e. Ice Cream Stick Kecombrang Josam. Can be made from chocolate ice cream that after being printed and stored in the freezer and then dipped into chocolate that has been melted and stored back in the freezer. Next packed in plastic.

f. Ice Cream Vanilla Kecombrang Josam. Made from 2 cups half and a half (Topping), one box of whippy cream, 300 cc cold sauté juice $(200+100$ ice water $)$, one-half teaspoon vanilla, $1 / 2$ cup sugar, 200 gr milk powder. Whippy cream is mix with $300 \mathrm{cc}$ of cold cum juice until blended, enter the other ingredients and mixer until thickened. Can be varied with topping, colour. Fill a cup, container, and store it in the freezer. Can also be shrunk.

g. Ice Cream Kecombrang Variation Josam Ice Cream Kecombrang Josam Variation 1. Made from $200 \mathrm{cc}$ juice kecombrang cold, 100 cc coca cola, I box fondant strawberry/vanilla, 200 sweetened condensed milk. Mix pounded with the juice of kecombrang and Fanta or coca cola, mixer until thickened, put milk and mixer until thick. Put it into ice cream mould/cup and save it in the freezer. Ice Cream Kecombrang Josam Variation 2. Made from $200 \mathrm{gr}$ milk powder + 200 cc juice sour +75 gr sugar, cooked until thick and then chill (called a material). Then one box whippy cream + ingredients a, mixer until thick, add dye according to taste. After that insert it into ice cream/cup mould and save it in freezer
From the results of hedonic test analysis and hedonic quality based on organoleptic test results base on taste, colour, texture and aroma, by panellists and consumers, using descriptive analysis [14]. Then that is the product with the standard prescription that has been designed, laboratory tested and field-tested most favoured and favoured by panellists and consumers among the experimental test results conducted in the laboratory and field (Figure 3). If the level of stakeholder and user preferences through organoleptic tests, interviews, observations, FGDs and questionnaires, (validation of Gregory's model contents) [24] [25]. It can explain that in general it is highly preferred, the colour, the smell, and the texture are also highly preferred. The most preferred are candy, and hard candy $(94 \%)$, vanilla ice cream and chocolate ice cream are preferred (93\%), instant drinks are preferred (75\%) [5]. The variety of products are in Figure 3:

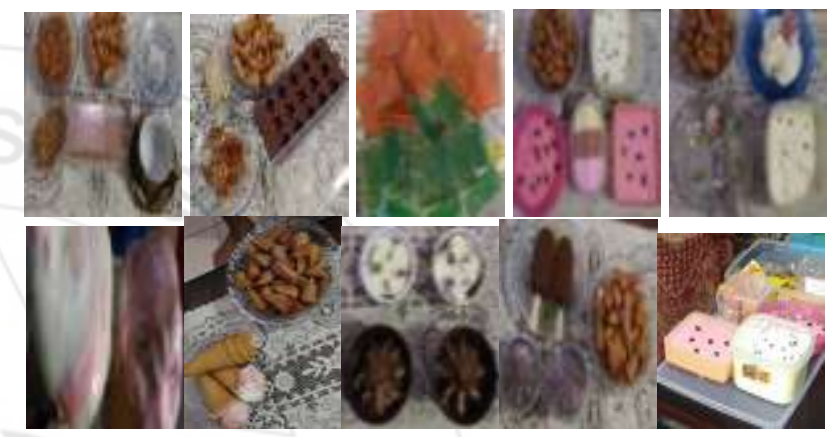

Figure 3: Various Products of Kecombrang Fruit are instant drinks, candy, hard candy, ice cream shavings, cup, scones, glass, stick, vanilla ice cream and ice cream variation.

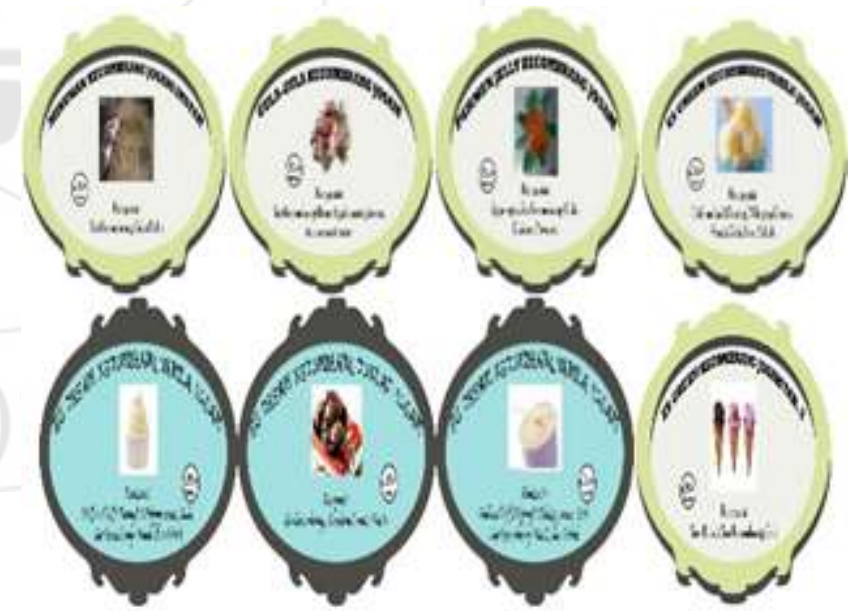

Figure 4: Label of Kecombrang Product Mark or Brand of Josam 


\section{International Journal of Science and Research (IJSR) \\ ISSN (Online): 2319-7064}

Index Copernicus Value (2015): 78.96 | Impact Factor (2015): 6.391

Table 1: Result of Nutrient Analysis of Kecombrang Products

\begin{tabular}{|c|c|c|c|c|c|c|c|c|}
\hline No & $\begin{array}{c}\text { Nutritional/ } \\
\text { Parameter }\end{array}$ & Unit & $\begin{array}{l}\text { Instant } \\
\text { drink }\end{array}$ & Candy & Hard candy & $\begin{array}{c}\text { Stick } \\
\text { Kecombrang }\end{array}$ & $\begin{array}{c}\text { Vanilla Ice Cream } \\
\text { Kecombrang }\end{array}$ & Metode Specification \\
\hline 1 & Carbohydrate & $\%$ & 32.45 & 77.22 & 41.66 & 17.43 & 31.27 & Titrimetric \\
\hline 2 & Fat & $\%$ & 2.10 & 0.47 & 0.27 & 1.18 & 1.13 & Kjeldhal \\
\hline 3 & Protein & $\%$ & 2.30 & 0.26 & 0.53 & 1.93 & 2.21 & Gravimetric \\
\hline 4 & Water & $\%$ & 2.10 & 1.05 & 8.57 & 45.99 & 29.05 & Gravimetric \\
\hline 5 & $\mathrm{P} 2 \mathrm{O} 5$ & $\%$ & 0 & 2.14 & 0 & 24.74 & 0 & Spectrophotometric \\
\hline 6 & Rough Fiber & $\%$ & 39.56 & 2.14 & 2.04 & 8.90 & 10.07 & Gravimetric \\
\hline 7 & Calcium $(\mathrm{Ca})$ & $\mu \mathrm{g} / \mathrm{g}$ & 1617.36 & 71.95 & 191.49 & 1502.8 & 1959.70 & Atomisasi \\
\hline 8 & Sodium $(\mathrm{Na})$ & $\mu \mathrm{g} / \mathrm{g}$ & 48.74 & 117.65 & 59.85 & 139.24 & 184.69 & Atomisasi \\
\hline 9 & Zinc (Zn) & $\mu \mathrm{g} / \mathrm{g}$ & 31.32 & 2.29 & 2.88 & 2.01 & 1.79 & Atomisasi \\
\hline 10 & Iodine & $\mu \mathrm{g} / \mathrm{g}$ & 0 & 0 & 0 & 0 & 0 & Spectrophotometric \\
\hline 11 & Vitamin C & $\mu \mathrm{g} / \mathrm{g}$ & 960.14 & 2116.72 & 358.03 & 357.20 & 488.53 & Spectrophotometric \\
\hline
\end{tabular}

The highest carbohydrate nutrient element in Candy products is $77.22 \%$, and the Stick Kecombrang product has the lowest sugar component of $17.43 \%$. The highest fat nutritional elements are in Instant Drink products of $2.10 \%$, and Hard Candy products have the lowest fat nutrient element of $0.27 \%$. The maximum protein nutrient found in Instant Drink products is $2.30 \%$, and Candy products have the most economical protein nutrient by $0.26 \%$. The maximum water nutrition element is in Stick Kecombrang product $45.99 \%$, and Candy has the lowest water food component of $1.05 \%$. The highest part of P2O5 nutrient found in Stick Kecombrang products of $24.74 \%$ and Instant Drink, Hard Candy, and Vanilla Ice Cream products have no P2O5 element. The highest crude fibre nutrient element found in Instant Drink products is $39.56 \%$, and Hard Candy products have the lowest rough grain nutrient at $2.04 \%$. The maximum calcium nutrient element submitted to Vanilla Ice Cream products of $1959.70 \mu \mathrm{g} / \mathrm{g}$ and the Candy product has the least calcium nutrient element of $71.95 \mu \mathrm{g} / \mathrm{g}$. The highest nutrient sodium element found in Vanilla Ice Cream product of $184.69 \mu \mathrm{g} / \mathrm{g}$ and Vanilla Ice Cream has the lowest nutrient sodium part of $48.74 \mu \mathrm{g} / \mathrm{g}$. The highest nutritional component of Zinc is in Instant Drink product of $31.32 \mu \mathrm{g} / \mathrm{g}$, and Vanilla Ice Cream product of Kecombrang has the lowest Zinc nutritional element of $1.79 \mu \mathrm{g} / \mathrm{g}$. All these products do not have the ingredients of Iodine nutrition. The highest Vitamin C dietary component is in Candy products of $2116.72 \mu \mathrm{g} / \mathrm{g}$, and the Stick Kecombrang product has the lowest Zinc nutrient element of $357.20 \mu \mathrm{g} / \mathrm{g}$ [26].

\section{Conclusion}

From the summary of the results of survey analysis in the community, all parts of the kecombrang, ranging from roots/tubers, bamboo shoots, stems, young shoots, leaves, nodules, flowers, fruit, can be used for vegetables, medicines, spices, chilli, soap and deodorant. The Writer has been researching the use of kecombrang fruit into a variety of beverage products drinks and instant drinks, various ice cream, candy, hard candy, with the right formula, taste quality, colour, texture, aroma, endurance, label and packaging is better so deserve a high-value for home industry. The result has been the prototype of Josani flavoured various beverage model, which has packaged in bottles and glass, and prototype models of ice cream products different, cup or stick, candy, jelly candy, instant beverage ingredients in the form of the sachet, with brand Josam.
Everything can sell as a result of the home industry, as well as the community can cultivate plants kecombrang as raw materials because it has the benefits and benefits very well. Thus, people have new jobs as well as a more productive source of income in the field of beverage, candy, hard candy, various of ice cream and agricultural products kecombrang. The impact will extend nationwide throughout the archipelago.

\section{Acknowledgements}

During carrying out the research to the writing of this article the writer has obtained the help and donations are very valuable from various parties, therefore, through this paper the author say thank the greatest to all parties who have contributed to help and provide donations morality and materials/funds for the implementation of research and writing of this article. Among others to the honorable: Minister of Research and Technology Risbang, Rector of UNM, PR IV, Chairman of UNM Research Institute and his staff, Dean of the Technical Faculty and his team, Chairman of PKK, Research Team Members, Lecturers, Panelist, Laboran, North Toraja Regent/ Gavenor and the Community, Students involved, Husband and my Son who helped, and UNM ICESAT Committee, International Journal Manager that load this article. We apologise profusely if there is the mistake, which is not accidental.

\section{References}

[1] DP3M Dirjen Dikti, Panduan Pelaksanaan Penelitian dan Pengabdian kepada Masyarakat di Perguruan Tinggi Edisi IX. Jakarta: Direktorat Jenderal Pendidikan Tinggi Kementerian Pendidikan Dan Kebudayaan, 2013.

[2] Kementerian Riset Teknologi dan Pendidikan Tinggi, Panduan Pelaksanaan Penelitian dan Pengabdian kepada Masyarakat di Perguruan Tinggi, IX. Jakarta: Direktorat Riset dan Pengabdian Kepada Masyarakat, Direktorat Jenderal Penguatan Riset dan Pengembangan Kementerian Riset, Teknologi, dan Pendidikan Tinggi, 2016.

[3] Tarmizi, 'Kecombrang I: Kecombrang Obat Sakit Telinga, Memperbanyak Asi, Deodoran, Pencuci Darah dan Luka', 2011. [Online]. Available: http://tarmiziblog.blogspot.co.id/2011/04/kecombrang.ht $\mathrm{ml}$.

[4] J. Saludung and Syamsidah, 'Prosfek Pengembangan

\section{Volume 6 Issue 9, September 2017}




\section{International Journal of Science and Research (IJSR) \\ ISSN (Online): 2319-7064}

Index Copernicus Value (2015): 78.96 | Impact Factor (2015): 6.391

Buah Kecombrang Menjadi Industri Rumah Tangga', Makassar, 2015.

[5] J. Saludung and Syamsidah, 'Prosfek Pengembangan Buah Kecombrang Menjadi Industri Rumah Tangga', Makassar, 2016.

[6] Sanni, 'Pemanfaatan Buah Kecombrang dalam Pembuatan Sirup untuk Menambah Pendapatan Keluarga di Desa Minanga Kab. Mamasa', Universitas Negeri Makassar, 2012.

[7] Wikipedia, 'Kecombrang', Wikipedia. 2016.

[8] F. Agustina, Sambal Komplit Selera Nusantara. Yogyakarta: Jogja Great publisher, 2011.

[9] T. Plomp, Design Methodology and Developmental Research in/on Educational Training. Faculty of Educational Science and Technology (TEST) University of Twente, Enschede, the Netherlands, 1982.

[10] S. V Falletta, 'Evaluating Training Programs: The Four Levels: Donald L. Kirkpatrick, Berrett-Koehler Publishers, San Francisco, CA, 1996, 229 pp.' No longer published by Elsevier, 1998.

[11] J. Saludung, Joke Models and Development Result and Benefits. Makassar: Proceedings ICMSTEA, 2014.

[12]Departemen Pendidikan Nasional, Pedoman Pelaksanaan Program Pendidikan Berorientasi Keterampilan Hidup (Life Skills) Melalui Pendekatan Broad Base Education (BBE) dalam Bidang Pendidikan Luar Sekolah dan Pemuda. Jakarta: Direktorat Jenderal Pendidikan Luar Sekolah dan Pemuda, 2002.

[13]N. Sudjana, 'Belajar dan Faktor-faktor yang Mempengaruhinya'. Jakarta: Rineka Cipta, 2010.

[14]H. Stone, R. Bleibaum, and H. A. Thomas, Sensory evaluation practices. Academic press, 2012.

[15]U. Sekaran and R. Bougie, Research methods for business: A skill building approach. John Wiley \& Sons, 2016.

[16] Partodiredja, Perkembangan Ekonomi. Jakarta: Penerbit Swadaya, 2002.

[17]J. Saludung and Syamsidah, Buku Ajar Pelatihan dan Pemberdayaan Masyarakat Berbasis Home Industri. Makassar: Hasil Penelitian Stranas. Lemlit UNM., 2016.

[18] J. Saludung and Syamsidah, Model Joke Sebagai Model Penelitian dan Pengembangan. Hasil Penelitian Stranas. Lemlit UNM, 2015.

[19]J. Saludung and Syamsidah, Model Pelatihan dan Pemberdayaan Masyarakat Berbasis Industri Rumah Tangga. Makassar: Hasil Penelitian Stranas. Lemlit UNM., 2015.

[20] J. Saludung, 'Prospects of Kecombrang Fruit Development Become Home Industry', Proceeding Int. Conf. Educ. Technol., pp. 61-73, 2015.

[21] A. Malik, 'Seleksi Panelis', 2010. [Online]. Available: https://billyjoeadam.wordpress.com/2010/03/08/seleksipanelis/. [Accessed: 18-Apr-2012].

[22] Y. Suryana and K. Bayu, 'Kewirausahaan: Pendekatan Karakteristik Wirausahawan Sukses', Jakarta: Kencana, 2010.

[23] J. Saludung, 'Sirup Kecombrang Josani Aneka Rasa', Makassar, 2015.

[24] Ruslan, 'Validitas Isi', Buletin Pa' Biritta No. 10, 2009.

[25] Ratlin, Program Analisis Validasi Isi Menurut Gregori. Makassar: PEP Pascasarjana UNM, 2015.

[26] Balai Besar Laboratorium Kesehatan Makassar, 'Hasil
Analisis Kandungan Gizi Berbagai Produk Kecombrang Berdasarkan Sampel 1 Juli sampai 4 Agustus 2016', 2016.

Volume 6 Issue 9, September 2017

www.ijsr.net

Licensed Under Creative Commons Attribution CC BY 